\title{
Perbaikan Sudut Daun Populasi Komposit Tanaman Jagung Melalui Hibridisasi dengan Varietas Hibrida
}

\author{
Leaf Angle Improvement of Corn Composite Population Through \\ Hybridization with Hybrid Varieties
}

\author{
I Wayan Sudika*, Dwi Ratna Anugrahwati \\ Program Studi Agroekoteknologi, Budidaya Pertanian Fakultas Pertanian Universitas Mataram \\ *Corresponding Author Email: sudikawayanms@ gmail.com
}

Manuscript received: 08-12-2020. Accepted: 26-10-2021

\begin{abstract}
ABSTRAK
Penelitian ini bertujuan untuk mengetahui rata-rata sudut daun, umur panen dan daya hasil F1 hasil persilangan komposit dengan hibrida; nilai heterosis dan mengetahui efek maternal ketiga sifat tersebut pada tanaman jagung. Percobaan telah dilaksanakan di lahan sawah irigasi teknis mulai bulan November 2019 sampai dengan bulan Februari 2020. Rancangan yang digunakan adalah rancangan acak kelompok, dua ulangan dan perlakuannya sebanyak 28 F1. Data hasil percobaan dianalisa dengan analisis sidik ragam dan diuji lanjut dengan uji BNT pada taraf nyata 5 persen. Nilai heterosis dihitung atas dasar tetua yang nilainya lebih tinggi. Hasil penelitian menunjukkan, rata-rata sudut daun galur F1 hasil persilangan dan resiprok P8IS vs NK212 sama dengan kedua tetua; sedangkan persilangan P8IS vs NK7328 berbeda. Resiprok persilangan nomor 13 (P8IS vs Nk7328 (R13) memiliki sudut daun lebih kecil dibanding P8IS dan sama dengan sudut daun NK7328. Umur panen super genjah diperoleh pada hasil persilangan P8IS vs NK212 nomor 1, 5; persilangan P8IS vs NK3728 nomor 11 dan 12. Daya hasil antar galur F1 kedua macam persilangan sama dengan masingmasing kedua tetua; namun terjadi kecendrungan kenaikan daya hasil dibanding P8IS untuk sebagian besar galur F1. Terjadi perubahan sifat sudut daun, umur panen dan daya hasil galur F1 dibanding salah satu tetua terbaik dengan nilai heterosis bersifat negatif dan positif dengan variasi dari 0.00 hingga 65.70 persen. Ketiga sifat pada kedua macam persilangan tidak menunjukkan efek maternal. Sudut daun yang lebih kecil, umur panen tetap super genjah dan daya hasil lebih tinggi, sangat dimungkinkan diperoleh pada galur-galur kedua macam persilangan.
\end{abstract}

Kata kunci: daya hasil; heterosis; efek maternal; sudut daun; umur panen

ABSTRACT
his study aims to determine the average leaf angle, harvest age and yield of F1 from cross-hybrid composite; heterosis value and knowing the maternal effect of these three traits on maize. The experiment was carried out in technically irrigated rice fields from November 2019 to February 2020. The design used in this experiment was a randomized block design, two replications and The treatment was $28 \mathrm{~F} 1$. The experimental data were analyzed by means of analysis of variance and further tested with the LSD test at the 5 percent level. Heterosis values were calculated on the basis of the parents whose scores were higher (High Parent Heterosis). The results showed that the mean leaf angles of F1 lines from crosses and reciprocal P8IS vs NK212 were the same as the two parents; whereas the P8IS vs NK7328 cross is different. The reciprocal of cross number 13 (P8IS vs Nk7328 
/R13) has smaller leaf angle than P8IS and is the same as the leaf angle of NK7328. The yield of the F1 lines from the two types of crosses was the same as each of the two parents; however, there was a tendency for an increase in yield compared to P8IS for most of the F1 lines. There was a change in leaf angle properties, harvest age and yield of F1 lines compared to one of the best parents with heterosis values are negative and positive with variations from 0.00 to 65.70 percent. Coefficient of correlation between heterosis with the average value of traits was classified as strong for the harvest age; moderate for yield and weak for leaf angle. These three traits in the two types of crosses showed no maternal effects. Smaller leaf angle, super early harvest age and higher yield, are possible to be obtained from the lines of both crosses.

Keyword: yield; heterosis; maternal effect; leaf angle; harvest age

\section{PENDAHULUAN}

Sekitar 60 persen penanaman jagung di Indonesia dilakukan di lahan kering, sehingga sangat diperlukan varietas yang tahan terhadap cekaman kekeringan (Indriani dan Mejaya, 2012). Varietas unggul merupakan salah satu faktor penting dalam usaha meningkatkan produktivitas tanaman jagung. Selanjutnya Suherman dan Awaludin (2007) mengatakan benih jagung bermutu yang murni dari varietas jagung komposit dapat menjamin tercapainya produktivitas tinggi. Salah satu faktor penentu produktivitas adalah populasi. Populasi yang optimum untuk menghasilkan produktivitas maksimal tergantung dari kanopi selama fase pengisian biji, yakni cahaya yang diteruskan sekitar 95 persen (Andrade et al., 2002). Salah satu penentu populasi optimum adalah sudut daun.

Populasi P8IS merupakan populasi hasil seleksi yang memiliki daya hasil lebih tinggi dibandingkan varietas unggul (Gumarang) Populasi ini memiliki umur panen super genjah di lahan kering dan sudut daun yang lebar (Sudika, et al., 2019). Peningkatan daya hasil masih dapat dilakukan dengan memperbaiki sudut daun, yakni lebih kecil. Sudut daun yang lebih kecil menunjukkan daun-daun lebih tegak, sehingga lebih efektif memanfaatkan cahaya matahari dan dapat ditanam lebih rapat. Disisi lain, varietas hibrida beredar sekarang termasuk hibrida komersial dengan sudut daun kecil. Hasil pengamatan pendahuluan, bahwa sudut daun P8IS berkisar 500 - 60o; sedangkan hibrida NK212 rata-rata 33,100, dan NK7328, 31,250. Berdasarkan data tersebut, maka telah dilakukan P8IS dengan Hibrida NK212 dan NK7328 dengan tujuan untuk memperoleh galur yang memiliki sudut daun dengan umur panen tetap super genjah dan hasil minimal sama dengan P8IS.

Guna memperoleh keturunan yang memiliki sudut daun lebih kecil dibanding P8IS, umur panen genjah/super genjah dan daya hasil tinggi, maka telah dilakukan hibridisasi secara resiprok dan dihasilkan sejumlah F1. Galur-galur F1 ini telah dievaluasi untuk memberikan gambaran terhadap terjadinya kombinasi sifat-sifat pada F1 tersebut, sekaligus dapat dikaji heterosis dan efek maternal sifat kuantitatifnya.

\section{BAHAN DAN METODE}

\section{Bahan}

Bahan yang digunakan dalam penelitian ini adalah galur-galur F1 sebanyak 28 Galur dengan rincian hasil persilangan P8IS vs hibrida NK212 sebanyak 10 dan hasil persilangan P8IS vs NK7328 sebanyak 18 galur, P8IS, NK212 dan NK7328. Bahan-bahan lain, yaitu pupuk Phonska Urea dan pupuk organik Petroganik serta pestisida (Calaris 550 SC, Furadan 3G dan Saromyl $35 \mathrm{SD})$. 


\section{Metode Penelitian dan Rancangan Percobaan}

Metode eksperimental digunakan dalam penelitian ini dengan percobaan di lahan sawah irigasi teknik, yakni di lahan praktek Fakultas Pertanian di desa Lembuak Lombok Barat. Percobaan dimulai bulan November 2019 sampai dengan bulan Februari 2020. Ketinggian tempat sekitar $250 \mathrm{~m}$ dpl. Rancangan yang digunakan dalam percobaan ini adalah rancangan acak kelompok dengan dua ulangan. Jumlah perlakuan sebanyak 31 genotipe, yaitu 28 galur F1 hasil persilangan dan resiproknya serta 3 tetua.

\section{Pelaksanaan}

Persiapan lahan meliputi pengolahan tanah, pembuatan blok-blok dan saluran irigasi. Pengolahan tanah, dilakukan dengan membajak dan menggaru masing-masing satu kali menggunakan hand traktor. Tanah yang telah diolah pada petak percobaan, kemudian diratakan. Selanjutnya petak percobaan dibagi dua; masing-masing dengan ukuran 52,8 x 4 $\mathrm{m}$. Setiap bagian merupakan satu blok. Jarak antar blok $1 \mathrm{~m}$ dan dibuat saluran selebar $40 \mathrm{~cm}$. Pada sekeliling petakan juga dibuat saluran irigasi untuk memperlancar pembuangan air hujan

Benih jagung yang digunakan terlebih dahulu diberi Saromyl 35 SD dengan dosis sebanyak $5 \mathrm{~g} / 1$. Hal ini dilakukan untuk mencegah penyakit bulai. Penanaman dilakukan dengan menggunakan jarak tanam $20 \times 60 \mathrm{~cm}$. setiap perlakuan terdapat dua baris dalam satu baris ditanam 20 tanaman. Pembuatan lubang tanam, dilakukan dengan menggunakan tugal sedalam sekitar $5 \mathrm{~cm}$. Jumlah benih per lubang sebanyak 1 biji. Pada setiap lubang tanam diisi Furadan $3 \mathrm{G}$ dengan dosis $20 \mathrm{~kg} / \mathrm{ha}$. Selanjutnya lubang tanam ditutup dengan pupuk organik Petroganik dengan dosis $500 \mathrm{~kg} / \mathrm{ha}$.

Pemupukan dilakukan dengan menggunakan pupuk Phonska dosis $300 \mathrm{~kg} / \mathrm{ha}$ dan 200 $\mathrm{kg} / \mathrm{ha}$ Urea yang diberikan 2 kali. Pemupukan pertama diberikan pupuk Phonska dengan dosis $150 \mathrm{~kg} / \mathrm{ha}$ saat tanam ditambah $100 \mathrm{~kg} / \mathrm{ha}$ Urea. Pemupukan kedua pada umur 30 hari setelah tanam pupuk Phonska dengan dosis $150 \mathrm{~kg} / \mathrm{ha}$ dan $100 \mathrm{~kg} / \mathrm{ha}$ pupuk Urea. Pupuk diberikan dengan cara ditugal kedalaman 9-10 cm disamping tanaman dan ditutup tanah.

Pengairan tanaman jagung bersumber dari air irigasi teknis. Pengairan dilakukan dengan cara dilab yakni petakan diairi hingga air rata dengan tanah kemudian air dibiarkan hingga meresap ke dalam tanah. Pengairan dilakukan pada umur 10 hari dan 24 hari sejak tanam. Pengairan selanjutnya tidak dilakukan karena turun hujan.

Penyulaman dilakukan pada 10 hari setelah tanam dengan memindahkan tanaman cadangan yang ditanam di antara barisan di dalam plot. Pengendalian gulma dilakukan dengan menggunakan herbisida Calaris. Penyemprotan dilakukan pada umur 15 hari setelah tanam. Konsentrasi yang digunakan adalah $75 \mathrm{cc} / 16$ liter air (3 cc/liter air). Pembumbunan tanaman jagung dilakukan 1 minggu setelah penyemprotan Calaris dengan cara mencangkul tanah di antara barisan tanaman, kemudian tanah tersebut ditempatkan pada barisan tanaman di sebelah kiri dan kanan.

Pengendalian hama dan penyakit tanaman jagung yaitu dengan menggunakan Furadan 3G yang diberikan pada lubang tanam pada saat tanam. Pengendalian penyakit bulai pada tanaman jagung menggunakan saromyl 35 SD. Pengendalian hama dan penyakit berikutnya tidak dilakukan karena tidak ada serangan hama dan penyakit pada percobaan. Panen 
dilakukan apabila tanaman telah menunjukkan kriteria panen, yaitu kelobot dan rambut tongkol telah kering dan biji telah mengeras apabila ditekan dengan kuku tidak berbekas.

\section{Variabel Yang Diamati dan Analisis Data}

Variabel yang diamati meliputi sudut dan, umur panen dan daya hasil. Sudut daun diamati pada fase pengisian biji. Umur panen, diperoleh dengan menghitung hari sejak tanam hingga 85 persen tanaman setiap plot telah siap dipanen. Daya hasil diukur dari bobot biji kering pipil per tanaman.

Data hasil percobaan dianalisa dengan analisis sidik ragam pada taraf nyata 5 persen. Apabila $\mathrm{F}$ hitung perlakuan lebih besar dibanding $\mathrm{F}$ tabel, maka dilakukan uji lanjut dengan uji beda nyata terkecil (BNT) pada taraf nyata 5 persen.

Nilai heterosis diperoleh, dengan rumus sebagai berikut (Ujianto, et al., 2020).

Keterangan :

$$
\mathrm{HPH}=\left[\frac{\mathrm{F} 1-\mathrm{HP}}{\mathrm{HP}}\right] \times 100 \%
$$

F1 =Rerata penampilan suatu galur.

HP =Rerata penampilan tetua tertinggi.

Selanjutnya, dibuat tiga katagori, yaitu rendah, sedang dan tinggi didasarkan atas nilai heterosis yang diperoleh.

Nilai efek maternal diperoleh dengan rumus sebagai berikut:

$\operatorname{ME}(\%)=(\mathrm{Gx}-\mathrm{Gy}) / \mathrm{Gy} \times 100$

Dengan

$\mathrm{ME}=$ nilai efek maternal

$\mathrm{Gx}=$ galur hasil persilangan/resiproknya dengan nilai lebih tinggi

Gy = galur hasil persilangan/resiproknya dengan nilai lebih rendah.

Uji t pada taraf nyata 5 persen, dihgunakan untuk mengetahui nyata/ tidaknya maternal efek suatu sifat.

Korelasi antara heterosis dengan rata-rata setiap sifat dihitung dengan rumus sebagai berikut

$$
r=\frac{N \Sigma X Y-(\Sigma X)(\Sigma Y)}{\sqrt{N \sum X^{2}-\left(\sum X\right)^{2}} \sqrt{N \sum Y^{2}-\left(\sum Y\right)^{2}}}
$$

Tingkat keeratan hubungan antar variabel ditetapkan dengan mengikuti kriteria Guilford (1956 cit. Somantri \& Muhidin, 2006), seperti disajikan pada Tabel 1.

Tabel 1 Tingkat keeratan hubungan antar variabel berdasarkan nilai koefisien korelasi (r)

\begin{tabular}{ccc}
\hline \multicolumn{2}{c}{ Kisaran Nilai Koefisien Korelasi (r) } & Katagori \\
\hline Bertanda positif & Bertanda negatif & Sangat Lemah \\
$0.00<\mathrm{r}<0.20$ & $-0.20<\mathrm{r} \leq 0.00$ & Lemah \\
$0.20 \leq \mathrm{r}<0.40$ & $-0.40<\mathrm{r} \leq-0.20$ & Sedang \\
$0.40 \leq \mathrm{r}<0.70$ & $-0.70<\mathrm{r} \leq-0.40$ & Kuat \\
$0.70 \leq \mathrm{r}<0.90$ & $-0.90<\mathrm{r} \leq-0.70$ & Sangat Kuat \\
$0.90 \leq \mathrm{r}<1.00$ & $-1.00<\mathrm{r} \leq-0.90$ & \\
\hline
\end{tabular}




\section{HASIL DAN PEMBAHASAN}

\section{Hasil}

Nilai rerata setiap sifat pada persilangan P8IS vs Nk 212 disajikan pada Tabel 2 dan untuk persilangan P8IS vs NK7328 disajikan pada Tabel 3. Pada Tabel 4 dan Tabel 5, disajikan berturut-turut untuk nilai heterosis setiap galur untuk persilangan P8IS vs NK212 dan P8IS vs NK7328. Pada Tabel 6, disajikan nilai efek maternal dan Tabel 7 disajikan keeratan hubungan nilai heterosis dengan rata-rata sifat.

Tabel 2. Rerata tiga sifat untuk galur F1 hasil persilangan P8IS vs NK212 dan resiproknya

\begin{tabular}{|c|c|c|c|c|}
\hline \multirow[b]{2}{*}{ No. } & \multirow[b]{2}{*}{ Galur/Tetua } & \multicolumn{3}{|c|}{ Sifat-sifat yang diamati $*$ ) } \\
\hline & & Sudut daun $\left(^{\circ}\right)$ & $\begin{array}{c}\text { Umur panen } \\
\text { (hari) }\end{array}$ & $\begin{array}{c}\text { Daya hasil (g } \\
\left.\tan ^{-1}\right)\end{array}$ \\
\hline 1 & Hasil $F_{1}$ P8IS x NK212 (1) & 53.75 & $78.00 \mathrm{a}$ & 99.38 \\
\hline 2 & Hasil resiprok P8IS x NK212 (R1) & 55.63 & $91.00 \mathrm{bc}$ & 74.75 \\
\hline 3 & Hasil $F_{1}$ P8IS x NK212 (2) & 53.75 & $85.00 \mathrm{a}$ & 73.19 \\
\hline 4 & Hasil resiprokP8IS x NK212 (R2) & 54.38 & $86.00 \mathrm{a}$ & 70.88 \\
\hline 5 & Hasil $F_{1} P 8 I S$ x NK212 (3) & 52.25 & $78.00 \mathrm{a}$ & 95.13 \\
\hline 6 & Hasil resiprok P8IS x NK212 (R3) & 54.00 & $98.00 \mathrm{ac}$ & 101.75 \\
\hline 7 & Hasil $F_{1}$ P8IS x NK212 (4) & 55.25 & $82.00 \mathrm{a}$ & 89.00 \\
\hline 8 & Hasil resiprok P8IS x NK212 (R4) & 55.63 & $88.00 \mathrm{a}$ & 85.49 \\
\hline 9 & Hasil $F_{1} P 8 I S$ x NK212 (5) & 47.50 & $85.00 \mathrm{a}$ & 84.75 \\
\hline 10 & Hasil resiprok P8IS x NK212 (R5) & 62.13 & $90.00 \mathrm{~b}$ & 75.25 \\
\hline 11 & Tetua NK212 & 49.50 & $95.00 \mathrm{c}$ & 58.38 \\
\hline 12 & Tetua P8IS & 51.88 & $79.00 \mathrm{a}$ & 71.63 \\
\hline
\end{tabular}

Keterangan: *) Angka-angka pada kolom sama diikuti oleh huruf sama tidak berbeda nyata dengan uji $\mathrm{BNT}_{0.05}$

Pada Tabel 2 ditunjukkan, bahwa seluruh galur hasil persilangan P8IS vs NK212 dan resproknya masing-masing, memiliki sudut daun sama dengan kedua tetua. Hal ini didasarkan atas analisis ragam, bahwa perlakuan tidak berbeda nyata. Galur resiprok hasil persilangan nomor 1 dan nomor 5 memiliki umur panen lebih dalam dibanding tetua P8IS. Galur hasil persilangan lain dan resiproknya, memiliki umur panen sama dengan P8IS; namun terdapat dua galur yang memiliki umur panen super genjah $(<80$ hari), yaitu persilangan nomor 1 dan nomor 3. Berdasarkan hasil analisis ragam, bahwa daya hasil perlakuan tidak berbeda nyata; berarti antar galur hasil persilangan P8IS vs NK212 dan resiproknya masing-masing sama dengan kedua tetua.

Tabel 3. Rerata tiga sifat yang diamati pada galur hasil persilangan P8IS vs NK7328 dan resproknya

\begin{tabular}{clccc}
\hline & & \multicolumn{2}{c}{ Sifat-sifat yang diamati *) } \\
\cline { 3 - 5 } No. Galur/Tetua & & Sudut daun $\left(^{\circ}\right)$ & Umur panen (hari) & $\begin{array}{c}\text { Daya hasil }(\mathrm{g} \\
\left.\tan ^{-1}\right)\end{array}$ \\
\hline 1 & Hasil F & & 85.63 \\
2 & Hasil resiprok P8IS x NK7328 (R6) & $49.38 \mathrm{~b}$ & $83.50 \mathrm{a}$ & 74.38 \\
3 & Hasil F1P8IS x NK7328 (7) & $61.63 \mathrm{~b}$ & $94.50 \mathrm{bc}$ & 66.00 \\
4 & Hasil resiprok P8IS x NK7328 (R7) & $48.13 \mathrm{~b}$ & $88.00 \mathrm{~b}$ & 71.25 \\
5 & Hasil F F8IS x NK7328 (8) & $40.63 \mathrm{bc}$ & $98.00 \mathrm{bc}$ & 87.50 \\
6 & Hasil resiprok P8IS x NK7328 (R8) & $47.25 \mathrm{bc}$ & $94.50 \mathrm{bc}$ & 46.50 \\
7 & Hasil F F8IS x NK7328 (9) & $59.38 \mathrm{~b}$ & $88.00 \mathrm{~b}$ & 78.88 \\
8 & Hasil resiprok P8IS x NK7328 (R9) & $56.00 \mathrm{~b}$ & $88.00 \mathrm{~b}$ & 93.63 \\
9 & Hasil F F8IS x NK7328 (10) & $58.75 \mathrm{~b}$ & $91.50 \mathrm{bc}$ & 91.00
\end{tabular}




\begin{tabular}{clccc}
\hline \multirow{2}{*}{ No. Galur/Tetua } & & \multicolumn{2}{c}{ Sifat-sifat yang diamati *) } \\
\cline { 3 - 5 } & & Sudut daun $\left(^{\circ}\right)$ & Umur panen (hari) & $\begin{array}{c}\text { Daya hasil }(\mathrm{g} \\
\left.\tan ^{-1}\right)\end{array}$ \\
\hline 10 & Hasil resiprok P8IS x NK7328 (R10) & $58.75 \mathrm{~b}$ & 73.00 \\
11 & Hasil F1P8IS x NK7328 (11) & $51.88 \mathrm{~b}$ & $78.00 \mathrm{bc}$ & 95.63 \\
12 & Hasil resiprok P8IS x NK7328 (R11) & $53.13 \mathrm{~b}$ & $86.50 \mathrm{a}$ & 92.75 \\
13 & Hasil F1P8IS x NK7328 (12) & $48.75 \mathrm{~b}$ & $79.00 \mathrm{a}$ & 87.25 \\
14 & Hasil resiprok P8IS x NK7328 (R12) & $41.00 \mathrm{bc}$ & $85.00 \mathrm{a}$ & 70.00 \\
15 & Hasil F1P8IS x NK7328 (13) & $49.25 \mathrm{~b}$ & $91.50 \mathrm{bc}$ & 86.90 \\
16 & Hasil resiprok P8IS x NK7328 (R13) & $34.50 \mathrm{c}$ & $85.00 \mathrm{~b}$ & 74.00 \\
17 & Hasil F1P8IS x NK7328 (14) & $51.88 \mathrm{~b}$ & $98.00 \mathrm{bc}$ & 38.38 \\
18 & Hasil resiprok P8IS x NK7328 (R14) & $54.38 \mathrm{~b}$ & $94.50 \mathrm{bc}$ & 70.13 \\
19 & Tetua NK7328 & $34.38 \mathrm{c}$ & $98.00 \mathrm{c}$ & 111.88 \\
20 & Tetua P8IS & $51.88 \mathrm{~b}$ & $79.00 \mathrm{a}$ & 71.63 \\
\hline \multicolumn{2}{c}{ Nilai BNT 0.05} & 13.59 & 8.64 & - \\
\hline
\end{tabular}

Keterangan: *) Angka-angka pada kolom sama diikuti oleh huruf sama tidak berbeda nyata dengan uji $\mathrm{BNT}_{0.05}$.

Pada Tabel 3 terlihat, bahwa galur resiprok persilangan P8IS vs NK7328 nomor 13 memiliki sudut daun lebih kecil dibanding sudut daun P8IS dan sama dengan sudut daun tetua hibridanya. Rata-rata sudut daun yang sama dengan tetua hibrida dan juga sama dengan tetua P8IS, yaitu resiprok nomor 6; hasil persilangan nomor 8 dan resproknya dan resiprok nomor 12. Umur panen hasil persilangan nomor 6; hasil persilangan nomor 11 dan 12 serta resiprok persilangan nomor 11 dan 12 sama dengan P8IS; sedangkan galur lainnya lebih dalam. Galur yang umur panennya tergolong super genjah, yaitu hasil persilangan nomor 11 dan nomor 12. Daya hasil semua galur sama dengan daya hasil kedua tetua.

Tabel 4. Nilai heterosis (\%) tiga sifat setiap galur hasil persilangan P8IS vs NK212 dan resiproknya

\begin{tabular}{|c|c|c|c|c|c|c|c|}
\hline \multirow[b]{2}{*}{ No. } & \multirow[b]{2}{*}{ Galur/Tetua } & \multicolumn{6}{|c|}{ Nilai heterosis $(\%)$ setiap sifat yang diamati } \\
\hline & & $\begin{array}{c}\text { Sudut } \\
\text { daun }\left(^{\circ}\right)\end{array}$ & Kotagori & $\begin{array}{l}\text { Umur } \\
\text { panen } \\
\text { (hari) }\end{array}$ & Katagori & $\begin{array}{c}\text { Daya } \\
\text { hasil ( } g \\
\tan ^{-1}\end{array}$ & Katagori \\
\hline 1 & Hasil F $F_{1}$ P8IS x NK212 (1) & 3.61 & Rendah & -17.89 & Sedang & 38.73 & Tinggi \\
\hline 2 & $\begin{array}{l}\text { Hasil resiprok P8IS x NK212 } \\
\text { (R1) }\end{array}$ & 7.23 & Rendah & -4.21 & Rendah & 4.36 & Rendah \\
\hline 3 & Hasil F F8IS x NK212 (2) & 3.61 & Rendah & -12.11 & Sedang & 2.17 & Rendah \\
\hline 4 & $\begin{array}{l}\text { Hasil resiprokP8IS x NK212 } \\
\text { (R2) }\end{array}$ & 4.82 & Rendah & -10.00 & Rendah & -1.05 & Rendah \\
\hline 5 & Hasil $F_{1}$ P8IS x NK212 (3) & 0.72 & Rendah & -17.89 & Sedang & 32.80 & Tinggi \\
\hline 6 & $\begin{array}{l}\text { Hasil resiprok P8IS x NK212 } \\
\text { (R3) }\end{array}$ & 4.10 & Rendah & -7.37 & Rendah & 42.05 & Tinggi \\
\hline 7 & Hasil F $F_{1}$ P8IS x NK212 (4) & 6.51 & Rendah & -13.68 & Sedang & 24.25 & Tinggi \\
\hline 8 & $\begin{array}{l}\text { Hasil resiprok P8IS x NK212 } \\
\text { (R4) }\end{array}$ & 7.23 & Rendah & -10.53 & Rendah & 19.34 & Sedang \\
\hline 9 & Hasil $F_{1} P 8 I S$ x NK212 (5) & -8.44 & Rendah & -10.53 & Rendah & 18.32 & Sedang \\
\hline 10 & $\begin{array}{l}\text { Hasil resiprok P8IS x NK212 } \\
\text { (R5) }\end{array}$ & 19.75 & Sedang & -4.74 & Rendah & 5.05 & Rendah \\
\hline & Rata-rata & 4.91 & & -10.89 & & 18.60 & \\
\hline
\end{tabular}

Atas dasar nilai heterosis yang diperoleh, dibuat katagori rendah, sedang dan tinggi. Katagori rendah: 0.00-11.17/-11.17-0.00; sedang 11.18-22.35/-22.35 - -11.18 dan tinggi; > $22.35 /<-22.35$. Heterosis sudut daun dan daya hasil pada Tabel 4, diukur dari tetua P8IS karena nilai P8IS untuk kedua sifat tersebut lebih tinggi; sedangkan umur panen dihitung dari 
tetua NK212. Nilai heterosis sudut daun yang semakin tinggi dengan tanda negatif, menunjukkan semakin tinggi berkurangnya sudut daun dibanding sudut daun P8IS. Umur panen yang nilai heterosis semakin tinggi dengan tanda negatif, menunjukkan semakin besar berkurangnya umur panen dibanding tetua NK212. Daya hasil yang semakin tinggi nilai heterosisnya dengan tanda positif; berarti semakin besar peningkatan daya hasil dibanding P8IS. Berdasarkan Tabel 4, bahwa hasil persilangan nomor 5 memiliki nilai heterosis negatif; berarti galur tersebut memiliki sudut daun cenderung lebih kecil dibanding sudut daun P8IS. Nilai heterosis umur panen seluruhnya negatif; berarti semua galur lebih genjah dibanding umur panen NK212. Nilai heterosis $-17.89 \%$ (Tabel 4). Daya hasil seluruh galur memiliki nilai heterosis positif; berarti terjadi peningkatan daya hasil dibanding P8IS, kecuali galur resiprok hasil persilangan nomor 2 memiliki nilai negatif; berarti terjadi penurunan daya hasil. Rata-rata nilai heterosis daya hasil lebih tinggi dibanding sudut daun dan umur panen. Heterosis sudut daun seluruh persilangan tergolong rendah, kecuali resiprok nomor 5, tergolong sedang. Umur panen memiliki heterosis tergolong rendah dan sedang berturut-turut sebanyak 6 dan 4. Heterosis daya hasil tergolong tinggi sebanyak 4 galur; sedang, 2 dan rendah, 4 galur.

Tabel 5. Nilai heterosis (\%) tiga sifat setiap galur hasil persilangan P8IS vs NK7328 dan resproknya

\begin{tabular}{|c|c|c|c|c|c|c|c|}
\hline \multirow[b]{2}{*}{ No. } & \multirow[b]{2}{*}{ Galur/Tetua } & \multicolumn{6}{|c|}{ Nilai heterosis (\%) setiap sifat yang diamati } \\
\hline & & $\begin{array}{l}\text { Sudut } \\
\text { daun }\end{array}$ & Katagori & $\begin{array}{l}\text { Umur } \\
\text { panen }\end{array}$ & Katagori & $\begin{array}{l}\text { Daya } \\
\text { hasil }\end{array}$ & Katagori \\
\hline 1 & Hasil $F_{1}$ P8IS x NK7328 (6) & -4.83 & Rendah & -14.80 & Sedang & -23.47 & Tinggi \\
\hline 2 & $\begin{array}{l}\text { Hasil resiprok P8IS x NK7328 } \\
\text { (R6) }\end{array}$ & -9.89 & Rendah & -3.57 & Rendah & -3352 & Tinggi \\
\hline 3 & Hasil F F88IS x NK7328 (7) & 18.78 & Sedang & -10.20 & Rendah & -41.01 & Tinggi \\
\hline 4 & $\begin{array}{l}\text { Hasil resiprok P8IS x NK7328 } \\
\text { (R7) }\end{array}$ & -7.24 & Rendah & 0 & Rendah & -36.32 & Tinggi \\
\hline 5 & Hasil $F_{1}$ P8IS x NK7328 (8) & -21.69 & Sedang & 0 & Rendah & -21.79 & Sedang \\
\hline 6 & $\begin{array}{l}\text { Hasil resiprok P8IS x NK7328 } \\
\text { (R8) }\end{array}$ & -8.92 & Rendah & -3.57 & Rendah & -58.44 & Tinggi \\
\hline 7 & Hasil $F_{1}$ P8IS x NK7328 (9) & 14.45 & Sedang & -10.20 & Rendah & -29.50 & Tinggi \\
\hline 8 & $\begin{array}{l}\text { Hasil resiprok P8IS x NK7328 } \\
\text { (R9) }\end{array}$ & 7.94 & Rendah & -10.20 & Rendah & -16.32 & Sedang \\
\hline 9 & Hasil $F_{1}$ P8IS x NK7328 (10) & 13.24 & Sedang & -6.63 & Rendah & -18.66 & Sedang \\
\hline 10 & $\begin{array}{l}\text { Hasil resiprok P8IS x NK7328 } \\
\text { (R10) }\end{array}$ & 13.24 & Sedang & 0.00 & Rendah & -34.75 & Tinggi \\
\hline 11 & Hasil F F P8IS x NK7328 (11) & -0.01 & Rendah & -19.90 & Sedang & -14.53 & Sedang \\
\hline 12 & $\begin{array}{l}\text { Hasil resiprok P8IS x NK7328 } \\
\text { (R11) }\end{array}$ & 2.40 & Rendah & -11.73 & Rendah & -17.10 & Sedang \\
\hline 13 & Hasil F F1P8IS x NK7328 (12) & -6.03 & Rendah & -19.39 & Sedang & -22.01 & Tinggi \\
\hline 14 & $\begin{array}{l}\text { Hasil resiprok P8IS x NK7328 } \\
\text { (R12) }\end{array}$ & -20.97 & Sedang & -13.27 & Sedang & -37.43 & Tinggi \\
\hline 15 & Hasil F F P8IS x NK7328 (13) & -5.07 & Rendah & -6.63 & Rendah & -22.33 & Tinggi \\
\hline 16 & $\begin{array}{l}\text { Hasil resiprok P8IS x NK7328 } \\
\text { (R13) }\end{array}$ & -33.50 & Tinggi & -10.20 & Rendah & -33.86 & Tinggi \\
\hline 17 & Hasil F F88IS x NK7328 (14) & -0.01 & Rendah & 0.00 & Rendah & -65.70 & Tinggi \\
\hline 18 & $\begin{array}{l}\text { Hasil resiprok P8IS x NK7328 } \\
\text { (R14) } \\
\text { Rata-rata }\end{array}$ & $\begin{aligned} & 4.81 \\
-2.41 & \end{aligned}$ & Rendah & $\begin{array}{l}-3.57 \\
-7.99\end{array}$ & Rendah & $\begin{array}{l}-37.32 \\
-31.34\end{array}$ & Tinggi \\
\hline
\end{tabular}


Pada Tabel 5, nilai heterosis umur panen dan daya hasil didasarkan atas NK7328 karena nilainya lebih tinggi dibanding P8IS; sedangkan sudut daun atas dasar P8IS. Sebanyak 11 galur memiliki nilai heterosis sudut daun negatif; berarti galur tersebut sudut daunnya lebih kecil dibanding P8IS. dan sisanya positif. Empat galur memiliki nilai heterosis nol; berarti umur panen sama dengan tetua NK7328; galur lainnya bernilai negatif; berarti umur panennya lebih genjah dibanding tetua NK7328. Pada Tabel 5 juga terlihat, bahwa nilai heterosis daya hasil seluruhnya negatif; berarti seluruh galur daya hasilnya lebih rendah dibanding NK7328. Nilai heterosis daya hasil lebih tinggi dibanding nilai heterosis sudut daun dan umur panen. Sebagian besar galur memiliki nilai heterosis sudut daun tergolong rendah, yakni 11 galur; tergolong tinggi hanya satu galur, yakni resiprok persilangan nomor 13 dan sisanya tergolong sedang, yakni sebanyak 6 galur. Heterosis umur panen tergolong rendah sebanyak 4 galur; sedang 14 galur dan tidak ada yang tergolong tinggi. Sebanyak 13 galur untuk daya hasil memiliki nilai heterosis tergolong tinggi; 5 galur tergolong sedang dan tidak ada galur yang tergolong rendah.

Tabel 6. Nilai maternal efek (\%) tiga sifat yang diamati untuk setiap macam persilangan

\begin{tabular}{clccc}
\hline No. & \multicolumn{1}{c}{ Macam persilangan } & \multicolumn{3}{c}{ Nilai efek maternal (\%) } \\
\cline { 3 - 5 } & & Sudut daun & Umur panen & Daya hasil \\
\hline 1 & Persilangan P8IS vs NK212 & $7.33 \mathrm{~ns}$ & $8.12 \mathrm{~ns}$ & $8.17 \mathrm{~ns}$ \\
2 & Persilangan P8IS vs NK7328 & $7.19 \mathrm{~ns}$ & $3.57 \mathrm{~ns}$ & $7.74 \mathrm{~ns}$ \\
\hline
\end{tabular}

Pada Tabel 6 terlihat, bahwa nilai maternal efek sudut daun, umur panen dan daya hasil untuk kedua macam persilangan bersifat tidak nyata. Hal ini berarti tidak ada maternal efek untuk ketiga sifat tersebut.

Tabel 7. Nilai koefisien korelasi antar nilai heterosis dengan rata-rata setiap sifat yang diamati

\begin{tabular}{clcc}
\hline No. & \multicolumn{1}{c}{ Sifat yang diamati } & Nilai koefisien korelasi & Kriteria \\
\hline 1 & Sudut daun & -0.34 & Lemah \\
2 & Umur panen & -0.80 & Kuat \\
3 & Daya hasil & -0.50 & Sedang \\
\hline
\end{tabular}

Pada Tabel 7 terlihat, bahwa sudut daun memiliki nilai koefisien korelasi tergolong lemah, yakni $-0,34$. Hal ini berarti peningkatan nilai heterosis memberikan kontribusi yang sangat sedikit terhadap penurunan sudut daun. Sebalinya pada sifat umur panen nilai koefisien korelasi sebesar 0.80 tergolong kuat. Semakin tinggi nilai heterosis, maka umur panen semakin genjah. Daya hasil nilai koefisien korelasinya sebesar 0.50 tergolong sedang; nilai heterosis semakin tinggi cukup besar pengaruhnya terhadap penurunan daya hasil.

\section{Pembahasan}

\section{Kajian perubahan rata-rata populasi akibat hibridisasi}

Hibridisasi bertujuan untuk menggabungkan karakter- karakter baik yang terdapat pada tanaman berbeda, menjadi satu genotipe baru. Hibridisasi dapat dilakukan dalam populasi maupun antar populasi (Anonymous, 2009 dan Lupi, 1995). Hasil hibridisasi tersebut dapat diseleksi untuk mendapatkan genotipe unggul sesuai kombinasi karakter yang 
diinginkan. Populasi P8IS merupakan populasi hasil rakitan kultivar lokal dengan varietas unggul komposit (Gumarang, Sukmaraga dan Lamuru); yang telah diseleksi selama 8 siklus dengan seleksi massa menggunakan teknik indeks seleksi dan dihasilkan komosit P8IS. Umur panen populasi ini tergolong super genjah, yakni < 80 hari (Sudika, et al., 2019a) Katagori tersebut sesuai dengan yang dikemukakan oleh Balitbang dan Balitsereal (2015). Rata-rata daya hasil di lahan kering adalah 7.097 t/ha dan populasi ini tahan terhadap cekaman kekeringan (Sudika, et al., 2019b). Disisi lain, sudut daun masih lebar, sehingga nampak daun agak terkulai. Hal ini merupakan kelemahan sifat populasi P8IS. Peningkatan sudut daun dapat dilakukan melalui hibridisasi dengan tetua yang memiliki sudut daun tergolong sempit. Varietas hibrida modern yang beredar, seperti NK212, NK7328, Bisi-18 dan Pioneer 21 umumnya memiliki sudut daun sempit, sehingga dapat ditanam pada jarak tanam yang lebih rapat (Jaya et al., 2019). Hibrida juga memiliki potensi hasil lebih tinggi dibanding komposit (Takdir et al.,2010). Dua keunggulan yang terdapat pada hibrida ini merupakan sifat yang ingin digabung dengan sifat umur panen super genjah dan tahan cekaman kekeringan yang ada pada P8IS. Penggabungan sifat-sifat unggul tersebut, telah dilakukan melalui hibridisasi secara resiprok menggunakan dua hibrida sebagai tetua, yaitu NK212 dan NK7328. Hasil hibridisasi tersebut berupa galur-galur F1.

Hasil evaluasi galur F1 menunjukkan, bahwa diperoleh satu galur yang memiliki sudut daun lebih kecil dibanding P8IS dan sama dengan tetua hibridanya, yakni galur resiprok persilangan P8IS vs NK7328 nomor 13. Tiga persilangan memiliki sudut daun sama dengan kedua tetua, yaitu resiprok persilangan nomor 6, 8 dan resiprok nomor 12. Persilangan P8IS vs NK212 menghasilkan seluruh galur F1 yang memiliki sudut daun sama dengan kedua tetua.

Umur panen super genjah diperoleh pada beberapa galur, yaitu hasil persilangan P8IS vs NK212 nomor 1 dan nomor 5 dan hasil persilangan P8IS vs NK7328 nomor 11 dan 12. Seluruh persilangan ini menggunakan P8IS sebagai tetua jantan. Hal ini sesuai dengan hasil penelitian Sudika (2016), bahwa gen umur super genjah dapat diwariskan dengan menggunakan populasi super genjah sebagai tetua jantan.

Daya hasil seluruh galur F1 sama dengan kedua tetua pada kedua macam persilangan. Kecendrungan kenaikan daya hasil dibanding kedua tetua, terjadi pada semua galur F1 hasil persilangan P8IS vs NK212. Seluruh galur hasil persilangan P8IS vs NK7328, cendrung turun dibanding tetua hibrida; namun sebagian besar cendrung naik dibanding P8IS, kecuali resiprok nomor 7, 8 dan resiprok nomor 14 .

Uraian di atas memberikan indikasi, bahwa hibridisasi dapat menghasilkan populasi dengan umur panen super genjah, sudut daun sempit dan daya hasil lebih tinggi dibanding P8IS. Masing-masing sifat yang diinginkan tersebut, tidak terdapat dalam satu galur; melainkan pada beberapa galur. Segregasi pada F2, akan menentukan galur-galur mana yang ditetapkan sebagai bahan untuk pembentukan populasi dasar, sehingga diperlukan evaluasi galur-galur F2.

\section{Kajian heterosis}

Heterosis merupakan gejala, bahwa persilangan dua genotipe berlainan dalam satu spesies menghasilkan keturunan F1 melebihi kedua tetuanya. Nilai heterosis dapat bertanda negatif atau positif. Tanda positif menunjukkan ada peningkatan; sedangkan tanda negatif 
menunjukkan adanya penurunan suatu sifat dibanding tetua (salah satu atau kedua tetua). Tujuan perbaikan sifat adalah agar galur-galur hasil persilangan memiliki sudut daun lebh kecil, daya hasil sama atau lebih tinggi dibanding P8IS serta umur panen tetap genjah. Sudut daun lebih besar diperoleh pada P8IS, sehingga nilai negatif yang diinginkan. Demikian pula umur panen karena kedua tetua umur panennya lebih dalam. Daya hasil persilangan P8IS vs NK212, diharapkan bertanda positif karena daya hasil P8IS lebih tinggi sedangkan persilangan P8IS vs NK7328, diharapkan bertanda positif atau negative; namun rata-rata tidak lebih rendah dibanding P8IS karena daya hasil NK7328 lebih tinggi.

Hasil evaluasi menunjukkan, sembilan galur memiliki nilai heterosis sudut daun bertanda positif dan tergolong rendah kecuali galur tergolong sedang. Satu galur bertanda negatif tergolong rendah untuk persilangan P8IS vs NK212 (Tabel 4). Hal ini berarti, perubahan sifat sudut daun kecil. Hal ini terlihat pada rata-rata sudut daun persilangan tersebut sama antar semua galur dengan kedua tetua (Tabel 2). Berlainan dengan perubahan sudut daun yang terjadi pada persilngan P8IS vs NK3728. Sebagian besar bertanda negatif; berarti terjadi perubahan sudut daun ke arah lebih kecil. Satu hasil persilangan, yakni resiprok nomor 13 memiliki heterosis tergolong tinggi bertanda negatif, menunjukkan penurunan yang besar. Pada Tabel 3 juga terlihat, bahwa galur tersebut memiliki sudut daun sama dengan tetua hibrida dan lebih kecil dibanding P8IS. Beberapa Galur F1 yang heterosis tergolong sedang dengan tanda negatif, menunjukan sudut daun sama dengan tetua hibrida dan tetua P8IS. Keeratan hubungan nilai heterosis dengan rata-rata sifat sudut daun bersifat negatif sebesar -0.34 dan tergolong lemah (Tabel 7); menunjukkan nilai heterosis semakin tinggi, maka penurunan sudut daun tidak terlalu besar.

Umur panen seluruh galur F1 hasil kedua macam persilangan, memiliki nilai heterosis bertanda negatif; menunjukkan terjadi perubahan ke arah lebih genjah. Keeratan hubungan nilai heterosis umur panen sebesar -0.80 tergolong kuat (Tabel 7); berarti peningkatan nilai heterosis besar pengaruhnya terhadap penurunan umur panen. Hal ini terlihat pada rata-rata umur panen galur-galur F1 hasil kedua macam persilangan, berubah secara nyata lebih genjah dibanding tetua hibrida dan banyak pula yang sama dengan umur panen P8IS. Empat galur memiliki umur panen super genjah, yaitu dua galur hasil persilangan P8IS vs NK212, yaitu (Tabel 3) dan nomor 11 dan 12 hasil persilangan P8IS vs NK7328 (Tabel 4) dan nilai heterosisnya tergolong sedang. Nilai heterosis galur-galur lain ada juga yang tergolong sedang dan rendah. Hal ini menunjukkan adanya perbedaan nilai heterosis setiap galur F1. Amzeri (2015) memperoleh hal sama, bahwa nilai heterosis untuk umur panen pada beberapa hasil persilangan pada jagung Madura berbeda-beda.

Nilai heterosis daya hasil galur F1 hasil persilangan P8IS vs NK212 seluruhnya bertanda positif; menunjukkan adanya peningkatan daya hasil dibanding tetua P8IS. Hal sama diperoleh oleh Setyowidianto, et al. (2017), bahwa hasil jagung memiliki nilai heterosis yang positif. Seluruh galur F1 hasil persilangan P8IS vs Nk7328 menunjukkan tanda negatif; berarti terjadi penurunan daya hasil dibanding daya hasil NK7328. Seberapa besar pengaruh kenaikan/penurunan nilai heterosis terhadap rata-rata daya hasil dapat dilihat dari nilai koefisien korelasi. Pada Tabel 7 terlihat bahwa nilai koefisien korelasinya sebesar -050 dan tergolong sedang; berarti nilai heterosis cukup berpengaruh terhadap kenaikan daya hasil. Hal ini terlihat dari rata-rata daya hasil kedua macam persilangan tidak berbeda dengan masingmasing kedua tetua; walaupun terjadi perubahan nilai heterosis. Iriani et al. (2011) juga 
memperoleh bahwa nilai heterosis hasil jagung bertanda positif dan negatif. Perbedaan respon heterosis pada hibrida sangat dipengaruhi oleh latar belakang genetik dari tetuanya atau populasi awal pembentuk tetua (Abuali et al., 2012).

Penyebab terjadinya heterosis dapat dijelaskan dari hipotesis dominan dan dominan lebih. Dalam hipotesis dominan, dijelaskan akumulasi gen-gen dominan yang lebih baik dalam satu genotipe menyebabkan munculnya fenomena heterosis; sedangkan penampilan gen-gen resesif akan tertutup atau hilang. Hipotesis dominan lebih menjelaskan, bahwa heterosis merupakan penampilan superioritas heterosigositas terhadap homosigositas. Hal ini berarti, individu yang memiliki pasangan allel dalam bentuk heterosigot terbanyak, maka individu tersebut memiliki sifat melebihi kedua tetua (Takdir, et al., 2010).

\section{Kajian efek maternal}

Pewarisan karakter dari tetua kepada keturunannya dapat terjadi dalam 2 (dua) mekanisme, yaitu pewarisan kromosomal (nukleus) dan pewarisan ekstrakromosomal. Pewarisan ekstrakromosomal adalah pewarisan yang dikendalikan oleh gen yang ada di luar inti sel. Salah satu ciri pewarisan ini yaitu keturunan hasil persilangan berbeda dengan keturunan hasil persilangan resiprokalnya (Syukur, et.al., 2015). Implikasinya adalah apabila ada efek maternal, maka untuk memindahkan sifat tersebut melalui hibridisasi, maka populasi tersebut digunakan sebagai tetua betina.

Hasil analisis menunjukkan, bahwa sudut daun, umur panen dan daya hasil menunjukkan tidak ada efek maternal. Nilai efek maternal yang diperoleh umur panen hampir sama untuk kedua macam persilangan, yaitu $7.33 \%$ untuk persilangan P8IS vs NK212 dan $7.19 \%$ untuk persilangan P8IS vs Nk7328. Efek maternal umur panen $8.24 \%$ untuk persilangan P8IS vs NK212 dan $3.57 \%$ untuk persilangan P8IS vs Nk3728; sedangkan daya hasil hampir sama untuk kedua macam persilangan tersebut. Hal ini berarti, ketiga sifat tersebut dikendalikan oleh gen-gen dalam inti. Kontribusi gen-gen dalam sitoplasma terhadap penampilan ketiga sifat tersebut sangat kecil. Hal sama diperoleh oleh Pamandungan dan Bartholomeus (2018) untuk sifat komponen hasil (berat tongkol, panjang tongkol, diameter tongkol dan jumlah biji per tongkol).

\section{KESIMPULAN}

Rata-rata sudut daun galur F1 hasil persilangan dan resiprok P8IS vs NK212 sama dengan kedua tetua; sedangkan persilangan P8IS vs NK7328 berbeda. Resiprok persilangan nomor 13 (P8IS vs Nk7328 (R13) memiliki sudut daun lebih kecil dibanding P8IS dan sama dengan sudut daun NK7328. Umur panen super genjah diperoleh pada hasil persilangan P8IS vNK212 nomor 1, 5, persilangan P8IS vs NK3728 nomor 11 dan 12. Daya hasil antar galur F1 kedua macam persilangan sama dengan masing-masing kedua tetua; namun terjadi kecendrungan kenaikan daya hasil dibanding P8IS untuk sebagian besar galur F1. Terjadi perubahan sifat sudut daun, umur panen dan daya hasil galur F1 dibanding salah satu tetua terbaik dengan nilai heterosis bersifat negatif dan positif dengan variasi dari 0.00 hingga 65.70 persen. Ketiga sifat pada kedua macam persilangan menunjukkan tidak ada efek maternal. Sudut daun yang lebih kecil, umur panen tetap super genjah dan daya hasil lebih tinggi, sangat dimungkinkan diperoleh pada galur-galur kedua macam persilangan. 


\section{DAFTAR PUSTAKA}

Andrade F H, Calviño P, Cirilo A and Barbieri P. 2002. Agron. J. 94: 975-980.

Abuali, A.I., A.A. Abdelmulla, M.M. Khalafalla, A.E. Idris and A.M. Osman. 2012. Combining ability and heterosis for yield and yield component in maize (Zea mays L.). Aust. J. Basic Appl. Sci. 6:36-41.

Amzeri, A. 2015. Evaluasi Nilai Heterosis dan Heterobeltiosis Pada Persilangan Dialel Tanaman Jagung Madura (Zea mays L). Agrosain vol 3 (2):286-295.

Anonymous. 2009. Metode Pembentukan Keragaman Genetik. http://pttipb. wordpress.com/category/04-pembentukan-keragaman-genetik-dan-pengujiannya/41metode-pembentukan-keragaman-genetik/ (Diakses, 19 Januari 2019).

Badan Litbang Pertanian dan Balitsereal. 2015. Penggunaan Benih Jagung Umur Genjah Merupakan Upaya untuk Meminimalkan Kegagalan Panen. http://cybex.pertanian.go.id/materipenyuluhan/detail/10038 (Diakses, 25 September 2019).

Indriani, F.C. dan Mejaya. 2012. Toleransi Genotipe Jagung Biji Putih terhadap Cekaman Kekeringan. Hal. 411 - 420. Prosiding Seminar Nasional Pusat Penelitian dan Pengembangan Tanaman Pangan, Badan Penelitian dan Pengembangan Pertanian.

Iriany, R. N. , S. Sujiprihati, M. Syukur, J. Koswara, dan M. Yunus. 2011. Evaluasi Daya Gabung dan Heterosis Lima Galur Jagung Manis (Zea mays var. saccharata) Hasil Persilangan Dialel. J. Agron. Indonesia 39 (2): 103 - 111.

Jaya, I K D., Sudirman and Sudika, I W. 2019. Light interception and yield of some maize varieties grown in a doublerow pattern under different urea applications. IOP Conf. Series: Earth and Enviromnental Science 346: 1-6. Lupi, C. 1995. Genetic Engineering for Plant Protection Methods, State of the Art and Applications. http://www.bats.ch/bats/publikationen/1995-1_TA/2-methods.php?lang_select $=$ de

(Diakses, 19 Januari 2019).

Pamandungan, Y. dan T. Bartholomeus O. 2018. Pewarisan Sifat Warna Dan Tipe Biji Jagung Manado Kuning. Eugenia vol 24 (1): 1-8.

Setyowidianto, E.P., Basuki, N. dan Damanhuri. 2017. Daya Gabung dan Heterosis Galur Jagung (Zea mays L.) pada Karakter Hasil dan Komponen Hasil. J. Agron. Indonesia 45(2):124-129.

Somantri A., Muhidin S.A. 2006. Aplikasi Statistika Dalam Penelitian. CV Pustaka Setia. Bandung.

Sudika, I W., Arya Parwata dan Soemeinaboedhy. 2019a. Respon seleksi massa dengan pengendalian dan tanpa pengendalian penyerbukan terhadap daya hasil Tanaman jagung di lahan kering. Prosiding Seminar Pertanian Ke-VI dan Lokakarya Nasional. FKPTPI. Hal.: 31-41.

Sudika, I W., Arya Parwata dan Soemeinaboedhy. 2019b. Seleksi Massa Guna Memperoleh Varietas Unggul Jagung Tahan Kering, Umur Panen Super Genjah, Hasil Dan Brangkasan Segar Tinggi. Laporan Hasil Penelitia (Tidak dipublikasi). Universitas Mataram, Mataram.

Sudika, I W. 2016. Kajian potensi hasil, ketahanan cekaman kekeringan dan umur panen hasil Hibridisasi pada tanaman jagung (Zea mays L.) Di lahan kering. (Disertasi). Program Pascasarjana Universitas Brawijaya, Malang. 
Suherman dan Awaludin. 2007. Budidaya Jagung Manis (Zea Mays Saccharata Sturt), Bahan Kursus Budidaya Jagung Manis dan Jagung Merang, Fakultas Pertanian IPB. Bogor Syukur, M., S. Sastrosumarjo, Y. Wahyu, S.I. Aisyah, S. Sujiprihati, dan R. Yunianti. 2015. Sitogenetika Tanaman. IPB Press. Bogor.

Takdir, A.M., S. Sunarti dan M.J. Mejaya. 2010. Pembentukan Varietas Jagung Hibrida. Hal. 74 - 95. Dalam Jagung: Teknik Produksi dan Pengembangan. Litbang Deptan. 